\title{
PR-14. INFLUENCE OF ORGANIC SOLVENTS AND SURFACTANTS ON PHOTOACTIVATION PROCESS OF DIELECTRIC MATERIALS
}

\author{
L. A. Brusnitsina, E. I. Stepanovskih, T. A. Alekseeva \\ Ural Federal University of the first President of Russia B. N. Yeltsin, \\ Mira St., 19, Yekaterinburg, 620002, Russia \\ E-mail: brusnitsyna.1@yandex.ru
}

Process of dielectric material metallization, in particular copper plating, is autocatalytic. The surface of the created copper covering acts as the catalyst. Concentration catalytically active centers on the dielectric surface has to be rather high for receiving a qualitative continuous copper covering [1].

Organic solvents (dimethylformamide and dimethylsulfoxide) are entered into photosensitive composition for increase in amount of copper (II) at the surfaces of dielectric. They are used at a stage of swelling of an epoxyrubber adhesive layer of fibreglasses by preparation of a dielectric surface. In this case, the photosensitive composition is fixed on the surface of dielectric not only due to microroughness, but also is capable to get deep into the bulked-up adhesive layer [2].

The amount of the copper (II) applied on the surface of dielectric as a part of photocomposition decided on the help of atomic and absorbing (AAMA) and X-ray diffraction the fluorescent analysis of methods (RSFA) [3, 4].

It is established that the amount of copper (II) on the surface of dielectric increases by 23 times at increase in time of drawing photocomposition from 0,5 to 5 of min. Thus the photosensitive layer is fixed on the dielectric surface not only due to microroughness, but also due to adsorption of photocomposition by an adhesive layer. It is shown that the amount of copper (II) on a surface is more, than when drawing photocomposition with dimetilformamidy when drawing on dielectric of the photocomposition containing $10 \%$ volume a dimethylsulfoxide.

It is shown that introduction to structure of the photoactivator of organic solvents increases concentration of copper (II) by surfaces and in an adhesive layer.

For the purpose of the best fixing of photocomposition on the surface of dielectric material the photoactivator was entered into structure of the photoactivator. Introduction to structure of the photoactivator of surfactants increases the speed of photorestoration of copper (II) in a dry layer of the photoactivator. Surfactants increase amount of copper (II) by the surfaces of dielectric and promote the best distribution of the photoactivator. Nonionic surfactant of the OP-10 brand as a part of the photoactivator considerably increases adhesion of a metal coating to dielectric.

\section{References}

1. Brusnitsina L. A., Stepanovskih E. I., Alekseeva T. A. Моделирование процесса фотовосстановления меди (II) в твердой фазе // Бутлеровские сообщения. 2012. Т. 29, № 1. С. 75-79.

2. Brusnitsina L. A., Stepanovskih E. I. Моделирование процесса набухания эпоксидно-каучукового адгезивного слоя в органических растворителях // Бутлеровские сообщения. 2015. Т. 44, № 12. С. 48-53.

3. Havezov I., Chalev D. Atomic-and-absorption analysis. L. : Chemistry, 1983. 144 p.

4. Losev N. F. Quantitative X-ray spectral analysis. M. : Science. 1969. 363 p. 